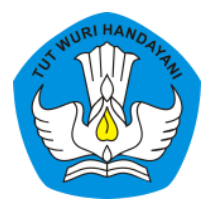

Page: $375-398$

\title{
PENGEMBANGAN MODEL PEMBELAJARAN ABAD 21 BERBASIS MEDIA PENANAMAN KARAKTER BERTEMA NILAI-NILAI PANCASILA DAN SADAR KONSTITUSI
}

\author{
Yunina Resmi Prananta \\ Sekolah Dasar Negeri Wonolelo, Jawa Tengah, Indonesia \\ Contributor Email: yuninaresmi@gmail.com
}

Received: Jan 23, 2021

Accepted: Jul 02, 2021

Published: Jul 30, 2021

Article Url: https://ojsdikdas.kemdikbud.go.id/index.php/didaktika/article/view/213

\begin{abstract}
The purpose of this article is to develop a media-based 21st-century learning model in the form of cognitive and affective learning media to cultivate Pancasila values and be aware of the constitution (SIPANCA), test the feasibility and practicality of the media, and measure the effectiveness of the media. The development method is used to refer to the development steps of Gall and Borg (2008) and adopted into five phases. The results of this development are the creation of final media with specifications by affective and cognitive goals, and this media is declared feasible by media experts and field users with high eligibility criteria with an average score of 3,875 out of a total score $4(3.875 / 4)$ for the validation of SIPANCA game; the validation of SIPANCA application (3.75/4); the validation of microcontroller-based SIPANCA shielding media (3.75/4); the practically test of SIPANCA game (3.875/4); the practically test of SIPANCA application (3.975/4); and the practically test of microcontroller-based SIPANCA shielding media (3.93/4). The development of a 21st-century media-based learning model of character with the theme of Pancasila values and awareness of the constitution provides theoretical benefits to the reference of studies in the fields of education, learning, and media development related to learning strategies in schools.
\end{abstract}

Keywords: Learning Model; Effective Media; Pancasila Cognitive; Character Education 


\begin{abstract}
Abstrak
Tujuan dari artikel ini untuk mengembangkan model pembelajaran abad 21 berbasis media berupa media pembelajaran kognitif dan afektif untuk penanaman nilai Pancasila dan sadar konstitusi (SIPANCA), menguji kelayakan dan kepraktisan media tersebut, dan mengukur efektifitas media. Metode pengembangan digunakan merujuk pada langkah pengembangan dari Gall dan Borg (2008) yang disederhanakan menjadi 5 langkah adopsi. Hasil dari pengembangan ini adalah terciptanya final media dengan spesifikasi sesuai dengan tujuan afektif dan kognitif, media ini dinyatakan layak oleh ahli media dan pengguna lapangan dengan kriteria kelayakan tinggi dengan rat-rata skor 3,875 dari total skor $4(3,875 / 4)$ untuk validasi game SIPANCA; validasi aplikasi SIPANCA (3,75/4); validasi media perisai SIPANCA berbasis mikrokontroler (3,75/4); uji kepraktisan game SIPANCA (3,875/4); uji kepraktisan aplikasi SIPANCA (3,9375/4); dan uji kepraktisan media perisai SIPANCA berbasis mikrokontroler (3,93/4). Adanya pengembangan model pembelajaran abad 21 berbasis media penanaman karakter bertema nilai-nilai Pancasila dan sadar konstitusi memberikan manfaat teoritik terhadap referensi kajian bidang pendidikan, pembelajaran, dan pengembangan media yang berkaitan dengan strategi pembelajaran di sekolah.
\end{abstract}

Kata Kunci: $\quad$ Model Pembelajaran; Media Afektif; Kognitif Pancasila; Pendidikan Karakter

\title{
A. Pendahuluan
}

Kondisi permasalahan moral yang terjadi pada remaja di berbagai negara di dunia perlu mendapatkan perhatian khusus, seharusnya materi tentang nilai karakter mudah dimengerti oleh siswa supaya proses penerapannya dalam pembelajaran berjalan dengan baik (Lijanporn \& Khlaisang, 2016, p. 1708). Melihat Indonesia berada dalam fase negara maju dan berkembang, sangatlah mungkin banyak terjadi permasalahan moral sebagai gradasi dari nilai-nilai karakter remaja. Indonesia adalah negara dengan dasar Pancasila, diharapkan Pancasila bisa menjadi sifat pribadi bagi masyarakat berbangsa dan bernegara, sehingga nilai-nilai Pancasila perlu ditanamkan pada anak terutama pada sejak usia dini (Dini, 2009, p. 115).

Masa sekarang ini agen moral sangat dibutuhkan dalam kehidupan bermasyarakat, karena penerapan moral sangat berkaitan dengan penentuan keputusan seseorang bermoral atau imoral (Critcher, 
Inbar, \& Pizarro, 2012, p. 309). Banyaknya pemberitaan kriminal di televisi (pembunuhan, tawuran sekolah, pencopetan, penjambretan dengan kekerasan, perkosaan, penganiyayaan, dll) bisa disimpulkan dengan analisis sederhana bahwa kondisi moral masyarakat di Indonesia cenderung menurun. Laporan penelitian terbaru menyatakan bahwa masalah korupsi, kriminal (pencurian, pembunuhan, penipuan, dan lainnya), tayangan media yang tidak mendidik, tawuran pelajar, narkoba, pergaulan bebas para remaja adalah contoh moral bangsa yang semakin jauh dari nilai-nilai luhur Pancasila (Fikriyah et al., 2014, p. 4).

Penelitian terbaru tentang moral dan etika dilakukan oleh beberapa ahli untuk mengungkap pertanyaan moral yang sering ditanyakan, seperti penelitian berikut yang melaporkan bahwa pengaruh pelaku tradisi sangat besar terhadap sikap seseorang mendefinisikan moral orang lainnya sehingga kadang persepsi tentang moral dan etika seseorang tidak selalu benar terhadap orang lainnya (Critcher et al., 2012, p. 310). Selanjutnya penelitian lain juga menyatakan bahwa menanamkan moral sejak dini sangat diperlukan untuk mengembangkan sikap dan perilaku yang mengarah kepada akhlak mulia sesuai dengan harapan sebuah bangsa (Dini, 2009, p. 115; Kurniawati \& Sunarso, 2019). Penelitian inovatif yang memilih media sebagai penyampai moral di sektor pendidikan melaporkan bahwa sikap membangun moral bangsa dibuktikan dengan keseriusan pemerintah membekali masa depan generasi muda, salah satunya dengan media komik yang bisa digunakan untuk menerapkan poin dari Pancasila (Fikriyah et al., 2014, p. 1). Pancasila yang rumusan sila-silanya terdapat dalam Pembukaan UUD NRI 1945 (sebutan untuk UUD 1945 setelah diubah) telah menjadi kesepakatan nasional bangsa Indonesia sebagai dasar negara, yaitu Negara Kesatuan Republik Indonesia, jati diri dan karakter bangsa Indonesia (Wiyono, 2016:10; Mohd Yusoff \& Hamzah, 2015).

Penelitian terdahulu telah menyatakan pentingnya penanaman moral, akhlak dan pendidikan karakter bagi sebuah bangsa (terutama generasi muda) sehingga bisa disimpulkan bahwa kita perlu membangun 
tradisi (Critcher et al., 2012, p. 315) untuk menanamkan moral sejak dini (Dini, 2009, p. 115), melalui pengembangan sikap dan perilaku ahlak mulia yang didukung juga oleh kebijakan pemerintah dan salah satu usahanya melalui media yang memotivasi (Fikriyah et al., 2014, p. 5). Penggunaan dan pengembangan media pembelajaran sangat diperlukan dalam proses pembelajaran, hal ini dikarenakan penggunaan media seadanya berupa buku teks secara terus menerus akan dapat menimbulkan kebosanan pada diri siswa dan berkurangnya motivasi belajar siswa (Gunawan, 2013: 109; (Lewis \& Ponzio, 2016). Penelitian lain oleh Rusman \& Riyana (2013:172) menyatakan bahwa manfaat media pembelajaran dalam proses pembelajaran adalah menumbuhkan motivasi belajar siswa dan materi pembelajaran akan lebih jelas maknanya sehingga memungkinkan siswa menguasai tujuan pembelajaran lebih baik.

Berdasarkan analisis ini maka rumusan masalah dalam penelitian ini adalah sebagai berikut: (1) Perlunya penyelesaian masalah di bidang pendidikan terkait dengan menurunnya moral dan karakter generasi muda, khususnya di sekolah, (2) Perlunya pengembangan media pembelajaran yang bisa menyelesaikan kesulitan ruang dan waktu dalam penerapan pendidikan karakter bermuatan penanaman nilai Pancasila dan sadar konstitusi, dam (3) perlunya penerapan kebijakan diseminasi model pembelajaran bermuatan penanaman nilai Pancasila dan sadar konstitusi yang sudah teruji layak dan efektif diterapkan di pembelajaran.

Penelitian ini mengarah kepada pentingnya dikembangkan sebuah model pembelajaran inovatif yang memanfaatkan media sebagai sarana penyampaian modern sesuai dengan perkembangan teknologi di abad 21. Maka tujuan dari penelitian ini adalah mengembangkan model pembelajaran abad 21 berbasis media yang memuat penanaman karakter bertema nilainilai pancasila dan sadar konstitusi, menguji kelayakan, kepraktisan dan efektifitas media yang dihasilkan dari model ini.

Manfaat teoritik hasil penelitian ini dalam jangka panjang sebagai kajian dari pemanfaatan media dengan kolaborasi terapan pendidikan karakter di sekolah untuk membelajarkan materi moral dan akhlak secara 
inovatif. Selain itu hasil dari uji kelayakan media dalam penelitian ini bisa digunakan untuk pertimbangan penerapan dalam proses pembelajaran dengan melibatkan intervensi penerapan kebijakan dari pemerintah.

\section{B. Metode}

Desain dalam penelitian ini mengadopsi langkap penelitian pengembangan dari Gall and Borg (2008) seperti pada Gambar 1, yang meliputi (1) Research and Information Collecting, (2) Planning, (3) Developing Preliminary Form of Product, (4) Preliminary Field Testing, (5) Main Product Revision, (6) Main Field Testing, (7) Operational Product Revision, (8) Operational Field Testing, (9) Final Product Revision, dan (10) Dissemination and Implementation.

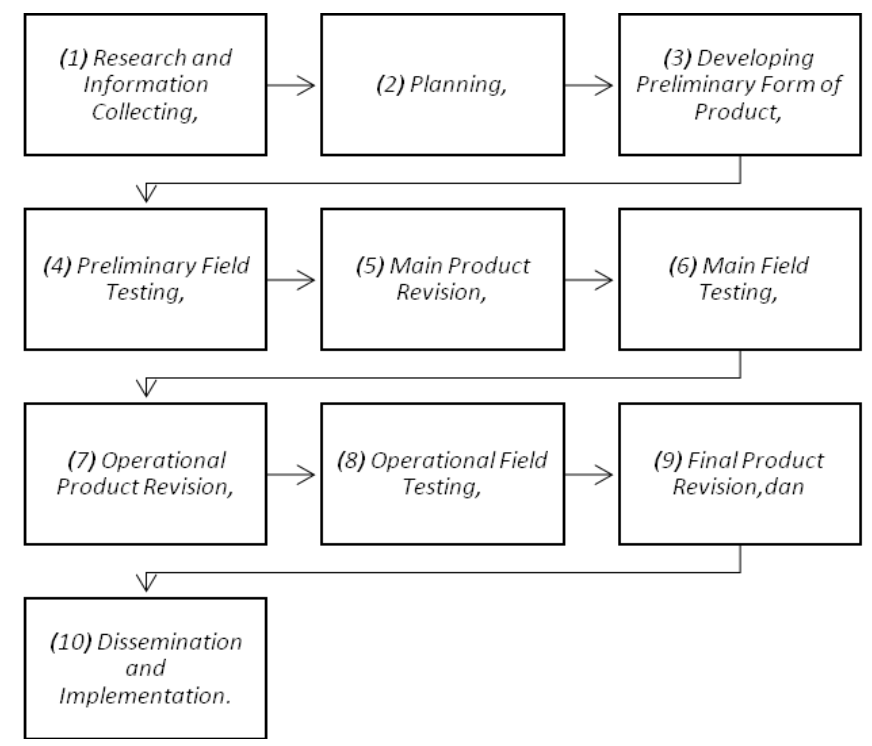

Gambar 1 Langkah Penelitian Borg \& Gall (2008)

Langkah dalam penelitian ini disederhanakan menjadi 5 tahap, hal ini tidak mengurangi esensi dari model Gall and Borg (2008) seperti pada Gambar 2, artinya tetap mewakili proses Riset dan Pengembangan yang dirujuk adalah (1) Pengumpulan Informasi, melalui mencari referensi terkait penanaman karakter siswa dalam mengamalkan nilai Pancasila dan sadar konstitusi di sekolah; (2) Perencanaan dan Pengembangan Produk Awal, 
melalui memutuskan materi yang tertuang dalam rencana pembelajaran yang dijadikan acuan untuk merancang dan mengembangkan model produk awal pemahaman sikap afektif dan kognitif melalui Media SIPANCA yang terdiri dari (a) Game SIPANCA, (b) Aplikasi SIPANCA, dan (c) Media Perisai SIPANCA berbasis Mikrokontroler; (3) Pengujian Produk terdiri dari (a) Kelayakan Produk Awal, (b) Revisi Produk Utama, (c) Pengujian Kepraktisan Produk Utama, (d) Revisi Produk Operasional; (4) Pengujian Keefektifan Produk Operasional, melalui uji-T pada kelas kontrol dan kelas eksperimen; (5) Finalisasi Produk Akhir dan Diseminasi.

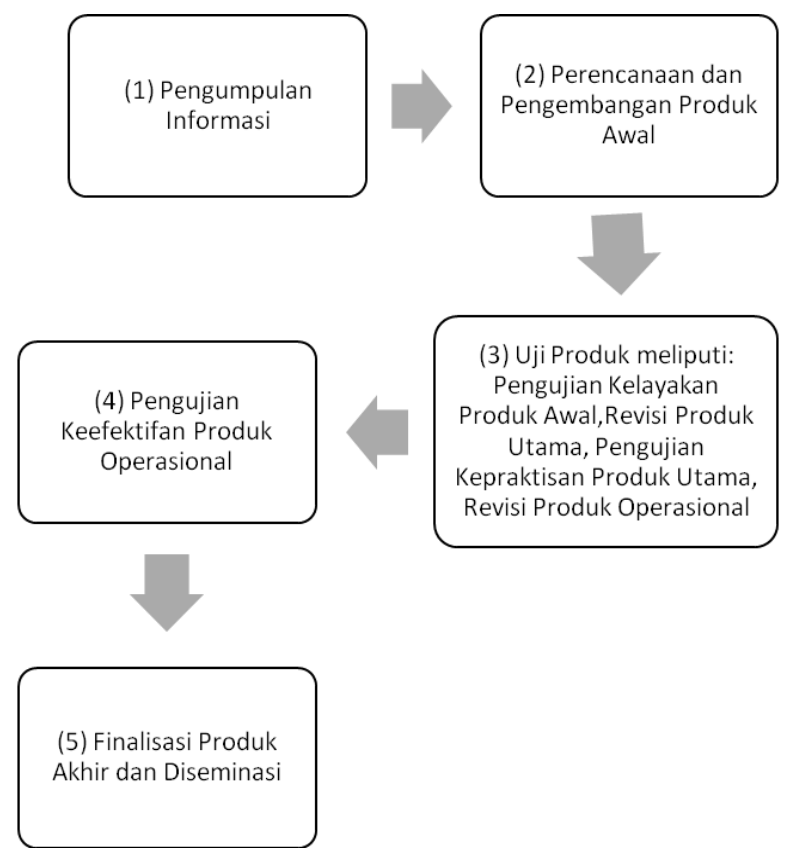

Gambar 2

Langkah Penelitian Adopsi Model Pengembangan Gall and Borg (2008)

Data dalam penelitian ini terdiri dari 3 data meliputi (1) data hasil kelayakan produk, (2) data kepraktisan produk, dan (3) data keefektifan produk. Data hasil kelayakan produk diperoleh melalui pengujian produk kepada 2 orang ahli. Kedua ahli tersebut adalah sebagai berikut (Tabel 1). 
Tabel 1 Validator Ahli dalam Pengujian Kelayakan Produk

\begin{tabular}{llccc}
\hline No. & \multicolumn{1}{c}{ Nama Ahli } & $\begin{array}{c}\text { Bidang } \\
\text { Keahlian }\end{array}$ & Institusi & Kode \\
\hline 1. & $\begin{array}{l}\text { Dr. Yuli Utanto, } \\
\text { S.Pd,.M.Si. }\end{array}$ & Kurikulum & Universitas Negeri & V1 \\
& $\begin{array}{l}\text { Ghanis Putra } \\
\text { Widhanarto S.Pd., }\end{array}$ & Teknologi & Universitas Negeri & V2 \\
M.Pd. & Pendidikan & Semarang & \\
\hline
\end{tabular}

Data kepraktisan produk diperoleh dengan meminta 2 orang guru menggunakan produk Media SIPANCA dalam kegiatan pembelajaran PPKn di kelas. Kedua guru tersebut adalah sebagai berikut (Tabel 2).

Tabel 2 Guru dalam Pengujian Kepraktisan Produk

\begin{tabular}{crrc}
\hline No. & \multicolumn{1}{c}{ Nama Guru } & \multicolumn{1}{c}{ Institusi } & Kode \\
\hline 1. & Siti Aisyah, S.Pd. & SDN Wonolelo & G1 \\
2. & Waljini, S.Pd. & SDN Wonolelo & G2 \\
\hline
\end{tabular}

Data keefektifan produk dalam penelitan ini terdiri dari 2 jenis data yaitu data nilai kognitif dan afektif karakter siswa dalam mengamalkan nilai Pancasila dan Sadar Konstitusi di sekolah. Kedua data tersebut diperoleh dari pengambilan data pada kelas yang diberikan Media SIPANCA maupun kelas kontrol.

Teknik pengumpulan data dalam penelitian ini terdiri dari 3 jenis meliputi (1) kelayakan produk, (2) angket, dan (3) tes.

\section{Kelayakan Produk}

Kelayakan produk dilakukan untuk mengetahui tingkat kelayakan sebuah produk media. Kelayakan produk dalam penelitian digunakan untuk mengukur kelayakan isi (konten), konstruksi, dan bahasa dari produk media. Kelayakan isi berkaitan dengan mampu tidaknya Media SIPANCA mengukur ketercapaian tujuan yang telah dirumuskan. Sementara, kelayakan konstruksi berkaitan dengan konstruksi Media SIPANCA itu sendiri. Sedangkan, kelayakan bahasa diukur dari bahasa yang digunakan 
pada Media SIPANCA. Media SIPANCA divalidasi oleh 2 validator meliputi 1 Ahli Teknologi dan 1 Ahli Pendidikan. Kelayakan produk dilakukan dengan menggunakan instrument lembar validasi.

\section{Angket}

Sugiyono (2009) menyatakan bahwa metode angket merupakan metode pengumpulan data yang dilakukan dengan cara memberi seperangkat pernyataan atau pertanyaan tertulis kepada responden untuk dijawabnya. Sedangkan menurut Arikunto (2009), metode angket adalah sejumlah pertanyaan tertulis yang digunakan untuk memperoleh informasi dari responden dalam arti laporan tentang pribadinya atau hal-hal yang ia ketahui.

Pada penelitian ini, metode angket digunakan untuk mengumpulkan data uji kepraktisan produk. Responden pada pengujian kepraktisan produk adalah 2 orang guru yang telah melaksanakan pembelajaran dengan menggunakan produk Media SIPANCA. Selain itu metode angket digunakan untuk mengumpulkan data uji efektivitas produk pada kemampuan afektif siswa kelas kontrol dalam pengamalan nilai Pancasila dan Sadar Konstitusi di sekolah. Berbeda dengan kelas kontrol, pada pengujian efektivitas produk pada kemampuan afektif siswa kelas yang diberikan Media SIPANCA tidak menggunakan metode angket. Data kemampuan afektif siswa kelas yang diberikan Media SIPANCA diperoleh dari hasil penginputan kegiatan melalui Aplikasi SIPANCA dan Media Perisai Pancasila berbasis Mikrokontroler.

\section{Tes}

Tes adalah serangkaian pertanyaan, latihan, atau alat lain yang digunakan untuk mengukur keterampilan, pengetahuan, intelegensi, kemampuan atau bakat yang dimiliki oleh individu atau kelompok (Arikunto, 2009). Metode tes digunakan untuk memperoleh data kemampuan kognitif siswa dalam mengamalkan nilai Pancasila dan Sadar Konstitusi di sekolah baik pada kelas yang diberikan Media SIPANCA maupun kelas kontrol. Pada penelitian ini, tes dikembangkan oleh penulis 
sendiri yang disesuaikan dengan 50 butir pengamalan nilai Pancasila dan Sadar Konstitusi di sekolah.

Teknik pengolahan data dalam penelitian ini meliputi (1) uji kelayakan produk, (2) uji kepraktisan produk, dan (3) uji efektivitas produk.

\section{Uji Kelayakan Produk}

Data hasil validasi oleh kedua ahli kemudian dirata-rata dan dibandingkan dengan kriteria tingkat kelayakan produk. Kriteria tingkat kelayakan produk dapat dilihat pada Tabel 3.

Tabel 3 Kriteria Tingkat Kelayakan Produk

\begin{tabular}{ll}
\hline Rata-rata Hasil Uji Kelayakan & \multicolumn{1}{c}{ Kriteria } \\
\hline $1 \leq x \leq 1,75$ & Sangat Kurang Layak \\
$1,75<x \leq 2,5$ & Kurang Layak \\
$2,5<x \leq 3,25$ & Layak \\
$3,25<x \leq 4$ & Sangat Layak \\
\hline
\end{tabular}

\section{Uji Kepraktisan Produk}

Data hasil pengujian kepraktisan oleh kedua responden guru kemudian dirata-rata dan dibandingkan dengan kriteria uji kepraktisan produk. Kriteria uji kepraktisan produk dapat dilihat pada Tabel 4.

Tabel 4 Kriteria Uji Kepraktisan Produk

\begin{tabular}{ll}
\hline \multicolumn{1}{c}{ Rata-rata Hasil Uji Praktis } & \multicolumn{1}{c}{ Kriteria } \\
\hline $1 \leq x \leq 1,75$ & Sangat Kurang Praktis \\
$1,75<x \leq 2,5$ & Kurang Praktis \\
$2,5<x \leq 3,25$ & Praktis \\
$3,25<x \leq 4$ & Sangat Praktis \\
\hline
\end{tabular}

\section{Uji Efektivitas Produk}

Uji Efektivitas produk dilakukan untuk mengetahui apakah kelas yang diberikan Media SIPANCA lebih baik dari kelas kontrol atau tidak dalam mengamalkan nilai Pancasila dan Sadar Konstitusi di Sekolah dari segi kognitif maupun afektif. Pengujian kedua data baik kognitif maupun 
afektif melalui 3 langkah pengujian yaitu (1) uji normalitas, (2) uji homogenitas, dan (3) uji perbedaan rata-rata (uji T).

a. Uji Normalitas

Hipotesis untuk uji normalitas data akhir adalah sebagai berikut :

$H_{0}$ : Sampel dari populasi berdistribusi normal.

$H_{1}$ : Sampel tidak dari populasi berdistribusi normal.

Uji normalitas dilakukan dengan menggunakan SPSS dengan uji Kolmogorov-Smirnov. Dengan derajat kepercayaan 5\%, apabila nilai signifikan pada Uji Kolmogorov-smirnov $>5 \%$, maka $H_{0}$ diterima artinya data berasal dari populasi yang berdistribusi normal (Sukestiyarno, 2013).

b. Uji Homogenitas

Hipotesis untuk uji homogenitas data akhir adalah sebagai berikut.

$H_{0} \quad: \sigma_{1}^{2}=\sigma_{2}^{2}$ (Sampel berasal dari populasi yang homogen)

$H_{1} \quad: \sigma_{1}^{2} \neq \sigma_{2}^{2}$ (Sampel berasal dari populasi yang tidak homogen)

Uji homogenitas pada penelitian ini menggunakan Levene Statistic Test dengan bantuan SPSS dengan taraf nyata 5\%. Kriteria penerimaan $H_{0}$ jika sig output $>$ 5\% (Sukestiyarno, 2013).

c. Uji Perbedaan Rata-rata

Hipotesis untuk uji perbedaan rata-rata adalah sebagai berikut.

$H_{0} \quad: \mu_{1} \leq \mu_{2} \quad$ (Rata-rata kemampuan kelas eksperimen kurang dari sama dengan kelas kontrol)

$H_{1}: \mu_{1}>\mu_{2} \quad$ (Rata-rata kemampuan kelas eksperimen lebih dari kelas kontrol)

Pengujiannya menggunakan statistik $t$ yang rumusnya sebagai berikut:

$$
t=\frac{\overline{X_{1}}-\overline{X_{2}}}{s \sqrt{\frac{1}{n_{1}}+\frac{1}{n_{2}}}}
$$


dengan :

$\overline{X_{1}}=$ rata - rata kelas eksperimen

$\overline{X_{2}}=$ rata - rata kelas kontrol

$s=$ standar deviasi dari data gabungan kelas eksperimen dan kontrol

$n_{1}=$ banyak siswa kelas eksperimen

$n_{2}=$ banyak siswa kelas kontrol

Kriteria pengujian yaitu terima $H_{0}$ jika $t$ hitung $\geq t_{1-\alpha}$ di mana $t_{1-\alpha}$ diperoleh dari distribusi t dengan peluang (1- $\alpha$ ). (Sudjana, 2005).

\section{Hasil dan Pembahasan}

Hasil dari penelitian ini adalah jabaran dari tujuan yang dilaksanakan menggunakan metode penelitian yang sudah ditentukan pada bab metode, sehingga tertulis secara sintesis untuk membuktikan langkah yang disampaikan pada desain penelitan. Sedangkan pembahasan dibahas setelah hasil peneltian disajikan, berikut jabaran dari hasil dan pembahasan.

Proses pengembangan media meliputi pengumpulan informasi dan kegiatan perencanaan dan pengembangan produk awal, secara lengkap dijabarkan berikut:

\section{Pengumpulan informasi}

Terdapat 50 butir pengamalam nilai Pancasila dan sadar konstitusi di sekolah menurut informasi yang sudah dikumpulkan. 


\begin{tabular}{|l|}
\hline 1. Ketuhanan Yang Maha Esa \\
\hline - Berdoa sebelum dan \\
sesudah pelajaran \\
- Melaksanakan sholat \\
berjamaah \\
- Tidakmengangguteman \\
yangsedang beribadah \\
(pasal 29,28 E) \\
- Menghormatisemuateman \\
meskipun berbeda agama \\
- Hidup rukun meskipun beda \\
agama \\
- Menulis kultum dengan \\
baik \\
- Membaca asmaulkhusna \\
dengan khusyuk \\
- Membuang sampah di \\
tempat sampah dilandasi \\
darikeyakinan bahwa \\
kebersihan sebagian dari \\
iman \\
- Mengingatkanteman ketika \\
tibawaktuibadah (pasal29, \\
28 E) \\
hembarga di kantin \\
\hline
\end{tabular}

\begin{tabular}{|c|}
\hline $\begin{array}{l}\text { 2. Kemanusiaan yang adil } \\
\text { dan beradab }\end{array}$ \\
\hline $\begin{array}{l}\text { - Menolong/memberi } \\
\text { bantuan teman yang } \\
\text { sakit/jatuh }\end{array}$ \\
\hline $\begin{array}{l}\text { - Menjengukteman yang } \\
\text { sakit di UKS }\end{array}$ \\
\hline $\begin{array}{l}\text { - Menjaga kerukunan antar } \\
\text { teman }\end{array}$ \\
\hline $\begin{array}{l}\text { - Berbuat adilterhadap } \\
\text { teman (pasal } 28 \mathrm{H})\end{array}$ \\
\hline $\begin{array}{l}\text { - Beranimembela teman } \\
\text { yangmelakukan kebenaran }\end{array}$ \\
\hline $\begin{array}{l}\text { - Tidakmemperlakukan } \\
\text { teman secara semau sendiri } \\
\text { (pasal } 28 \mathrm{E} \text { ) }\end{array}$ \\
\hline $\begin{array}{l}\text { - Berjabat tangan dan } \\
\text { menyapateman dengan } \\
\text { ramah }\end{array}$ \\
\hline $\begin{array}{l}\text { - Memberibantuan kepada } \\
\text { teman yang membutuhkan } \\
\text { atau dalam bencana (pasal } \\
\text { 34) }\end{array}$ \\
\hline $\begin{array}{l}\text { - Bersikap santun terhadap } \\
\text { guru dan teman }\end{array}$ \\
\hline $\begin{array}{l}\text { - Membantu guru dalam hal } \\
\text { apapun }\end{array}$ \\
\hline
\end{tabular}

\begin{tabular}{|l|}
\hline 3. Persatuan Indonesia \\
\hline - Bekerjasama dengan baik \\
saat diskusikelompok \\
- Mengikutiupacara bendera \\
dengan hikmad dan tertib \\
- Tidakterlambat ke sekolah \\
- Memakaiproduk buatan \\
dalam negeri \\
- Menjaga dan merawat bibit \\
tanaman sekolah (pasal 33 ) \\
- Tidak berkelahi dengan \\
teman \\
- Tidakgaduh di kelas (pasal \\
28 J) \\
- Mengerjakan PR dengan \\
penuh tanggungjawab \\
- Bergaul dengan semua \\
teman (pasal $28 \mathrm{I}$ ) \\
- Menyanyikan lagu \\
Indonesia Raya sebelum \\
pelajaran dengan hikmad \\
\end{tabular}

\begin{tabular}{|l|}
\hline $\begin{array}{c}\text { 4. Kerakyatan yang dipimpin oleh hikmat } \\
\text { kebijaksanaan dalam permusyawaratan } \\
\text { perwakilan }\end{array}$ \\
\hline - Tidakmemaksa kehendak sendiriterhadap \\
oranglain saat diskusi kelompok (pasal 28 \\
H) \\
- Mengutamakan bermusyawarah dalam \\
menyelesaikan masalah (pasal 28) \\
- Memiliki sifat lapang dada dalam menerima \\
keputusan hasil diskusikelompok \\
- Disiplin saat berbaris di depan kelas \\
- Menghargaiteman yang berbeda pendapat \\
saat diskusikelompok (pasal 28 ) \\
- Melaksanakan hasilmusyawarah dengan \\
ikhlas dan tanggungjawab \\
- Melaksanakan tugas piket harian dengan \\
tanggungawab sebagai hasil keputusan \\
bersama \\
- Mengutamakan kepentingan bersama/tidak \\
egois \\
- Memberikan kepercayaan kepada para \\
pengurus kelas dalam menjalankantugasnya \\
- Tepat waktu mengumpulkan tugas sekolah \\
\end{tabular}

\begin{tabular}{|l|}
\hline \multicolumn{1}{|c|}{ 5. Keadilan sosial bagi seluruh rakyat } \\
Indonesia
\end{tabular}

Gambar 3 Butir Pengamalan Pancasila

Merujuk pada gambar 1 setiap sila memiliki butir pengamalan yang berbeda, hal ini telah teridentifikasi pada studi awal untuk mengungkap tiap butir pengamalam per sila pada pancasila. 


\section{Perencanaan dan pengembangan produk awal}

Hasil dari pengumpulan informasi dirancang untuk membuat media dengan latar belakang fungsi yang berbeda (gambar 2), yaitu media meningkatkan nilai karakter siswa dalam mengamalkan nilai Pancasila dan sadar konstitusi di sekolah dari segi kognitif level C1 s.d C6 (Game SIPANCA ) dan media yang dikembangkan untuk menumbuhkan karakter siswa dalam mengamalkan nilai Pancasila dan sadar konstitusi di sekolah dari segi afektif level A1 s.d A5 (Media tersebut adalah aplikasi SIPANCA dan media perisai SIPANCA berbasis Mikrokontroler).

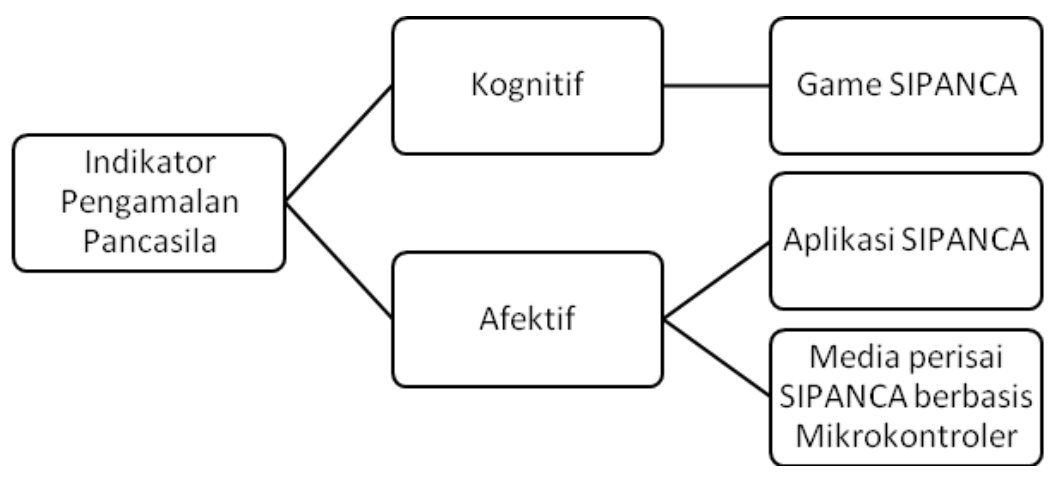

Gambar 4 Bagan Alir Konstruksi Media SIPANCA

\section{Uji kelayakan dan uji kepraktisan media}

Uji kelayakan model dilakukan dengan melibatkan ahli (expert judgement), untuk menilai kelayakan secara profesional terhadap model media yang sudah dikembangkan. Pada tahap ini, produk awal media SIPANCA yaitu (1) game SIPANCA, (2) aplikasi SIPANCA, dan (3) media perisai SIPANCA berbasis mikrokotroler diuji kelayakannya. Pengujian kelayakan dilakukan oleh 1 ahli teknologi dan 1 ahli pendidikan. Hasil validasi game Pancasila dari kedua validator disajikan pada Tabel 5. 
Tabel 5 Hasil Validasi Game SIPANCA

\begin{tabular}{|c|c|c|c|c|}
\hline \multirow[t]{2}{*}{ No. } & \multirow[t]{2}{*}{ Aspek yang dinilai } & \multicolumn{2}{|c|}{$\begin{array}{l}\text { Skor } \\
\text { Validator }\end{array}$} & \multirow{2}{*}{$\begin{array}{l}\text { Rata-rata } \\
(\mathrm{V} 1, \mathrm{~V} 2)\end{array}$} \\
\hline & & $\mathrm{V} 1$ & $\mathrm{~V} 2$ & \\
\hline & Konten & & & \\
\hline 1. & $\begin{array}{l}\text { Kesesuaian dengan materi Karakter Siswa } \\
\text { dalam Mengamalkan Nilai-nilai Pancasila } \\
\text { dan Sadar Konstitusi di Sekolah }\end{array}$ & 4 & 4 & 4 \\
\hline 2. & $\begin{array}{l}\text { Kesesuaian dengan Kurikulum } 2013 \text { mata } \\
\text { pelajaran PPKn }\end{array}$ & 4 & 4 & 4 \\
\hline 3. & $\begin{array}{l}\text { Originalitas } \\
\text { Konstruksi }\end{array}$ & 3 & 4 & 3,5 \\
\hline 4. & Kejelasan petunjuk cara menggunakan media & 4 & 4 & 4 \\
\hline 5. & Desain pada media & 4 & 4 & 4 \\
\hline 6. & $\begin{array}{l}\text { Kemudahan penggunaan media } \\
\text { Bahasa }\end{array}$ & 4 & 4 & 4 \\
\hline 7. & Kalimat pada media komunikatif & 3 & 4 & 3,5 \\
\hline 8. & Penggunaan Ejaan yang Disempurnakan (EYD) & 4 & 4 & 4 \\
\hline & Skor Total & 30 & 32 & 31 \\
\hline & Rata-rata Skor & 3,75 & 4 & 3,875 \\
\hline
\end{tabular}

Rata-rata skor validasi terhadap game sipanca dari kedua validator adalah 3,875. skor tersebut masuk ke dalam kriteria sangat layak. hasil validasi aplikasi SIPANCA dari kedua validator disajikan pada Tabel 6.

\begin{tabular}{|c|c|c|c|c|}
\hline \multicolumn{5}{|c|}{ Tabel 6 Hasil Validasi Aplikasi SIPANCA } \\
\hline \multirow[t]{3}{*}{ No. } & \multirow[t]{2}{*}{ Aspek yang dinilai } & \multicolumn{2}{|c|}{$\begin{array}{c}\text { Skor } \\
\text { Validator }\end{array}$} & \multirow{3}{*}{$\begin{array}{c}\text { Rata-rata } \\
(\mathrm{V} 1, \mathrm{~V} 2)\end{array}$} \\
\hline & & V1 & V2 & \\
\hline & Konten & & & \\
\hline 1. & $\begin{array}{l}\text { Kesesuaian dengan materi Karakter Siswa } \\
\text { dalam Mengamalkan Nilai-nilai Pancasila } \\
\text { dan Sadar Konstitusi di Sekolah }\end{array}$ & 4 & 4 & 4 \\
\hline 2. & $\begin{array}{l}\text { Kesesuaian dengan Kurikulum } 2013 \\
\text { mata pelajaran PPKn }\end{array}$ & 4 & 4 & 4 \\
\hline 3. & $\begin{array}{l}\text { Originalitas } \\
\text { Konstruksi }\end{array}$ & 3 & 4 & 3,5 \\
\hline 4. & Kejelasan petunjuk cara menggunakan media & 4 & 4 & 4 \\
\hline 5. & Desain pada media & 3 & 3 & 3 \\
\hline 6. & $\begin{array}{l}\text { Kemudahan penggunaan media } \\
\text { Bahasa }\end{array}$ & 4 & 4 & 4 \\
\hline 7. & Kalimat pada media komunikatif & 4 & 3 & 3,5 \\
\hline 8. & Penggunaan Ejaan yang Disempurnakan (EYD) & 4 & 4 & 4 \\
\hline & Skor Total & 30 & 30 & 30 \\
\hline & Rata-rata Skor & 3,75 & 3,75 & 3,75 \\
\hline
\end{tabular}


Rata-rata skor validasi terhadap aplikasi SIPANCA dari kedua validator adalah 3, 75. Skor tersebut masuk ke dalam kriteria sangat layak. Hasil validasi media perisai SIPANCA berbasis Mikrokontroler dari kedua validator disajikan pada Tabel 7.

Tabel 7 Hasil Validasi Media Perisai SIPANCA berbasis Mikrokontroler

\begin{tabular}{|c|c|c|c|c|}
\hline \multirow[t]{2}{*}{ No. } & \multirow[t]{2}{*}{ Aspek yang dinilai } & \multicolumn{2}{|c|}{$\begin{array}{c}\text { Skor } \\
\text { Validator }\end{array}$} & \multirow{2}{*}{$\begin{array}{l}\text { Rata-rata } \\
(\mathrm{V} 1, \mathrm{~V} 2)\end{array}$} \\
\hline & & V1 & $\mathrm{V} 2$ & \\
\hline & Konten & & & \\
\hline 1. & $\begin{array}{l}\text { Kesesuaain dengan materi Karakter } \\
\text { Siswa dalam Mengamalkan Nilai-nilai } \\
\text { Pancasila dan Sadar Konstitusi di } \\
\text { Sekolah }\end{array}$ & 4 & 4 & 4 \\
\hline 2. & $\begin{array}{l}\text { Kesesuaian dengan Kurikulum } 2013 \\
\text { mata pelajaran PPKn }\end{array}$ & 4 & 4 & 4 \\
\hline 3. & $\begin{array}{l}\text { Originalitas } \\
\text { Konstruksi }\end{array}$ & 3 & 4 & 3,5 \\
\hline 4. & $\begin{array}{l}\text { Kejelasan petunjuk cara menggunakan } \\
\text { media }\end{array}$ & 4 & 4 & 4 \\
\hline 5. & Desain pada media & 3 & 3 & 3 \\
\hline 6. & Kemudahan penggunaan media & 4 & 4 & 4 \\
\hline & Skor Total & 22 & 23 & 22,5 \\
\hline & Rata-rata Skor & 3,67 & 3,83 & 3,75 \\
\hline
\end{tabular}

Rata-rata skor validasi terhadap media perisai SIPANCA berbasis Mikrokontroler dari kedua validator adalah 3,75. Skor tersebut masuk ke dalam kriteria sangat layak. Ketiga media yang dikembangkan masuk ke dalam kriteria sangat layak. Ini berarti bahwa pengembangan media SIPANCA meliputi (1) game SIPANCA, (2) aplikasi SIPANCA, dan (3) media perisai SIPANCA berbasis mikrokontroler dapat dilanjutkan ke langkah penelitian berikutnya.

Langkah selnajutnya adalah revisi produk utama, pada tahap ini produk awal direvisi sesuai dengan masukan para ahli. Selain memberikan penilaian skor terhadap validitas produk media, V1 dan V2 juga memberikan masukan terhadap pengembangan media SIPANCA. 
Produk awal media SIPANCA diperbaiki berdasarkan masukan V1 dan V2 kemudian menjadi produk utama media SIPANCA.

Dilanjutkan langkah pengujian kepraktisan produk utama, pada tahap ini produk utama media SIPANCA meliputi (1) game SIPANCA, (2) aplikasi SIPANCA, dan (3) media perisai SIPANCA berbasis Mikrokontroler diuji kepraktisannya. Pengujian kepraktisan dilakukan dengan memberikannya kepada 2 orang guru. Kedua guru menggunakan media SIPANCA dalam pembelajaran PPKn di kelas kemudian diminta untuk mengisi instrumen uji kepraktisan produk. Hasil pengujian kepraktisan game SIPANCA dari kedua responden guru disajikan pada Tabel 8 .

Tabel 8 Hasil Pengujian Kepraktisan Game SIPANCA

\begin{tabular}{|c|c|c|c|c|}
\hline \multirow{2}{*}{ No. } & \multirow{2}{*}{ Aspek yang dinilai } & \multicolumn{2}{|c|}{ Skor Responden } & \multirow{2}{*}{$\begin{array}{c}\text { Rata-rata } \\
(\mathrm{G} 1, \mathrm{G} 2)\end{array}$} \\
\hline & & G1 & G2 & \\
\hline & Konten & & & \\
\hline 1. & $\begin{array}{l}\text { Kesesuaian dengan Kurikulum } 2013 \\
\text { mata pelajaran PPKn }\end{array}$ & 4 & 4 & 4 \\
\hline 2. & $\begin{array}{l}\text { Kesesuain dengan materi Karakter Siswa } \\
\text { dalam Mengamalkan Nilai-nilai Pancasila } \\
\text { dan Sadar Konstitusi di Sekolah }\end{array}$ & 4 & 4 & 4 \\
\hline 3. & Media memudahkan pembelajaran di kelas & 4 & 4 & 4 \\
\hline 4. & $\begin{array}{l}\text { Dampak media terhadap siswa } \\
\text { Konstruksi }\end{array}$ & 3 & 4 & 3,5 \\
\hline 5. & $\begin{array}{l}\text { Kejelasan petunjuk cara menggunakan } \\
\text { media }\end{array}$ & 4 & 3 & 3,5 \\
\hline 6. & $\begin{array}{l}\text { Waktu penggunaan media tidak } \\
\text { melebihi waktu jam pelajaran yang ada }\end{array}$ & 4 & 4 & 4 \\
\hline 7. & $\begin{array}{l}\text { Kemudahan penggunaan media } \\
\text { Bahasa }\end{array}$ & 4 & 4 & 4 \\
\hline 8. & $\begin{array}{l}\text { Kalimat pada media komunikatif } \\
\text { (mudah dipahami siswa }\end{array}$ & 4 & 4 & 4 \\
\hline & Skor Total & 31 & 31 & 31 \\
\hline & Rata-rata Skor & 3,875 & 3,875 & 3,875 \\
\hline
\end{tabular}

Rata-rata skor pengujian kepraktisan terhadap game SIPANCA dari kedua responden guru adalah 3,875. Skor tersebut masuk ke dalam kriteria sangat praktis. Hasil pengujian kepraktisan aplikasi SIPANCA dari kedua responden guru disajikan pada Tabel 9. 
Tabel 9 Hasil Pengujian Kepraktisan Aplikasi SIPANCA

\begin{tabular}{llll}
\hline & & \multicolumn{2}{c}{ Skor } \\
No. & Aspek yang dinilai & Responden & Rata-rata \\
& G1 & G2 & $(\mathrm{G} 1, \mathrm{G} 2)$ \\
\hline
\end{tabular}

\section{Konten}

1. Kesesuaian dengan Kurikulum 2013 mata pelajaran PPKn

$4 \quad 4 \quad 4$

Kesesuain dengan materi Karakter
2. Siswa dalam Mengamalkan Nilai-nilai
2. Pancasila dan Sadar Konstitusi di

$4 \quad 4$
4

Sekolah

3. Media memudahkan pembelajaran di

3. kelas

$\begin{array}{lll}4 & 4 & 4 \\ 4 & 4 & 4\end{array}$

Konstruksi

5. Kejelasan petunjuk cara menggunakan media

$4 \quad 3 \quad 3,5$

Waktu penggunaan media tidak

6. melebihi waktu jam pelajaran yang $4 \quad 4 \quad 4 \quad 4$ ada

7. Kemudahan penggunaan media

$4 \quad 4$

4

Bahasa

8. Kalimat pada media komunikatif (mudah dipahami siswa

$\begin{array}{ccc}4 & 4 & 4 \\ 32 & 31 & 31,5 \\ 4 & 3,875 & 3,9375\end{array}$

Rata-rata skor pengujian kepraktisan terhadap aplikasi SIPANCA dari kedua responden guru adalah 3,9375. Skor tersebut masuk ke dalam kriteria sangat praktis. Hasil pengujian kepraktisan media perisai SIPANCA berbasis Mikrokontroler dari kedua responden guru disajikan pada Tabel 10. 
Tabel 10 Hasil Pengujian Kepraktisan Media Perisai SIPANCA berbasis Mikrokontroler

\begin{tabular}{llll}
\hline & & \multicolumn{2}{c}{ Skor } \\
No. & Aspek yang dinilai & Responden & Rata-rata \\
& G1 & G2 & (G1, G2) \\
\hline
\end{tabular}

\section{Konten}

1. Kesesuaian dengan Kurikulum 2013 mata pelajaran PPKn

$\begin{array}{lll}4 & 4 & 4\end{array}$

Kesesuain dengan materi Karakter

2. Siswa dalam Mengamalkan Nilai-nilai

Pancasila dan Sadar Konstitusi di

$4 \quad 4$

4

Sekolah

3. Media memudahkan pembelajaran di kelas

4. Dampak media terhadap siswa Konstruksi

5. Kejelasan petunjuk cara menggunakan media

$\begin{array}{lll}4 & 4 & 4 \\ 4 & 4 & 4\end{array}$

6. Waktu penggunaan media tidak melebihi waktu jam pelajaran yang ada

7. Kemudahan penggunaan media

$$
\begin{gathered}
\text { Skor Total } \\
\text { Rata-rata Skor }
\end{gathered}
$$

34

$4 \quad 4$

Rata-rata skor pengujian kepraktisan terhadap media perisai SIPANCA berbasis Mikrokontroler dari kedua responden guru adalah 3,93. Skor tersebut masuk ke dalam kriteria sangat praktis. Ketiga media yang dikembangkan masuk ke dalam kriteria sangat praktis. Ini berarti bahwa pengembangan media SIPANCA meliputi (1) game SIPANCA, (2) aplikasi SIPANCA, dan (3) media perisai SIPANCA berbasis Mikrokontroler dapat dilanjutkan ke langkah penelitian berikutnya.

\section{Uji efektifitas media}

Sebelum menguji perbedaan rata-rata antara kedua kelas, data harus diuji normalitas dan homogenitasnya terlebih dahulu. Uji normalitas dilakukan dengan uji Kolmogorov-Smirnov pada SPSS. Hasil Uji 
Kolmogorov-smirnov diperoleh nilai signifikansi 0,161>0,05. Ini berarti data kemampuan kognitif berdistribusi normal. Sedangkan, uji homogenitas dilakukan dengan Levene Statistic Test pada SPSS. Hasil Levene Statistic Test diperoleh nilai signifikansi 0,628>0,05. Ini berarti data kemampuan kognitif pada kelas eksperimen dan kontrol homogen.

Hasil Uji Kolmogorov-smirnov pada data afektif siswa diperoleh nilai signifikansi 0,200 $>0,05$. Ini berarti data kemampuan afektif siswa berdistribusi normal. Sedangkan, hasil Levene Statistic Test diperoleh nilai signifikansi 0,780 >0,05. Ini berarti data kemampuan afektif siswa pada kelas eksperimen dan kontrol homogen.

Rata-rata hasil tes kemampuan kognitif pada kelas eksperimen dan kontrol berturut-turut adalah 87,833 dan 57,222 dengan nilai varians dari kedua kelas tersebut berturut-turut adalah $s_{1}^{2}=147,73$ dan $s_{2}^{2}=235,256$ sehingga dapat diperoleh nilai standar deviasi gabungan $s=13,838$. Jumlah siswa dari kedua kelas adalah 57 siswa. Berdasarkan perhitungan dengan bantuan software Microsoft Excel diperoleh nilai $t_{\text {hitung }}=8,339$ sedangkan $t_{\text {tabel }}=1,67$ sehingga $t_{\text {hitung }}>t_{\text {tabel }}$ maka dapat dinyatakan bahwa rata-rata kemampuan kognitif kelas eksperimen lebih dari rata-rata kemampuan kognitif kelas kontrol.

Rata-rata data hasil kemampuan afektif siswa pada kelas eksperimen dan kontrol berturut-turut adalah 44,833 dan 39,926 dengan nilai varians dari kedua kelas tersebut berturut-turut adalah $s_{1}^{2}=3,316$ dan $s_{2}^{2}=3,071$ sehingga dapat diperoleh nilai standar deviasi gabungan $s=3,194$. Berdasarkan perhitungan dengan bantuan software Microsoft Excel diperoleh nilai $t_{\text {hitung }}=10,352$ sedangkan $t_{\text {tabel }}=1,67$ sehingga $t_{\text {hitung }}>t_{\text {tabel }}$ maka dapat dinyatakan bahwa rata-rata kemampuan afektif siswa kelas eksperimen lebih dari rata-rata kemampuan kognitif kelas kontrol. 


\section{Finalisasi produk akhir dan diseminasi}

Finalisasi produk dilakukan setelah melewati proses uji kelayakan sehingga akhir dari revisi model ini adalah model final atau biasa disebut final project. Selanjutnya diseminasi model ini dilakukan melalui penyebaran dalam skala luas, hasilnya adalah luaran model berbentuk media diupload ke dalam playstore dengan tujuan bisa di-download dan dimanfaatkan oleh banyak orang melalui bantuan daring. Hasil dari model ini adalah luaran yang di diseminasikan, namun masih ada luaran tambahan yang memperkuat adanya model ini dan bisa dijadikan sebagai bukti kekayaan intelektual melalui terbitnya sertifikat HKI oleh Kementrian Hukum dan HAM. Luaran HKI ini adalah hasil dari turunan model yang berbentuk media. Selain proses penyebaran daring, juga dilakukan proses penyebaran secara face to face (tatap muka).

Menurut sebuah penelitian menyatakan bahwa media berbasis teknologi efektif dalam meningkatkan pemahaman konsep matematika peserta didik karena (Rusmana \& Isnaningrum, 2016, p. 204). Dikuatkan juga oleh penelitian lain tentang media yang menyatakan bahwa media video lebih efektif bila digunakan dalam pembelajaran metamorfosis ( $R$. P. Purnama \& Marsudi, 2017, p. 453). Sedangkan penelitian lain menyatakan bahwa "Students work dominantly using computer as alearning media, teachers usually implement learning based on ICT, it can complete the students learning outcomes also students and teachers response toward learning process based on ICT belong to good" (Sulistyorini, 2014, p. 145).

Langkah yang ditempuh dalam LKTI ini sudah mengawali denga analisis awal tentang penguasaan materi tertentu yaitu tentang nilai-nilai Pancasila, sedangkan media bernama sipanca yang terdiri dari tiga media untuk menguatkan kemampuan kognitif dan afektif siswa dijadikan sarana penyamapaian materinya, ICT sudah digunakan dengan basis media digital yang dioperasikan melalui komputer, smartphone dan penyebaran melalui sosial media google play sudah dilakukan. Dengan bukti ini maka sudah 
teridentifikasi bahwa proses LKTI ini sudah sesuai dengan beberapa teori yang disajikan dalam kajian penelitian yang berhubungan dengan media.

Kelayakan dan kepraktisan media menurut sebuah peneltian adalah pengolahan data hasil penelitian uji kelayakan dari ahli ahli materi, ahli media, dan praktisi pendidikan, serta penilaian dari dua orang pengamat pada perencanaan dan pelaksanaan pembelajaran tentang media pembelajaran (Wati et al., 2017, p. 303). Pada kondisi lapangan, LKTI ini telah menunjuk expert judgement untuk menguji kelayakan dan kepraktisan dari model yang dikembangkan, sehingga sudah sesuai dengan kajian di peneltian lain yang sejenis.

Efektifitas ditunjukan dengan pengukuran yang komprehensif, sebuah penelitan menyatakan bahwa "Findings suggest that the ability of media literacy messages to influence students' processing of the subsequent political program is conditioned by their preexisting media literacy education" (Vraga \& Tully, 2015, p. 12). Penelitian lainya juga menguatkan pernyataan ini yang melaporkan bahwa ada pengaruh penerapan media game mengetik interaktif berbasis Adobe Flash CS5 terhadap motivasi belajar (Wiwien \& Restu, 2019, p. 9). Penelitian lainnya juga menyatakan bahwa frekuensi akses media secara langsung hanya berpengaruh terhadap aspek kognitif (D. H. Purnama, Hubeis, \& Matindas, 2009, p. 453).

Model pembelajaran abad 21 berbasis media ini sudah mengukur kelayakan dengan menyatakan bahwa tingkatan gain dari kelas kontrol dan eksperimen telah membuktikan bahwa penerapan pada proses pembelajaran memberikan dampak positif. Terapan di sekolah dengan bukti peningkatan hasil belajar siswa pada kelas eksperimen maka aspek kognitif dan afektif pengguna media meningkat.

\section{Penutup}

Simpulan dari penelitian ini adalah pengembangan model pembelajaran abad 21 berbasis media yang memuat penanaman karakter bertema nilai-nilai Pancasila dan sadar konstitusi ditempuh dalam desain 
adopsi dari Gall and Borg (2008) yaitu terdiri dari lima langkah pengembangan. Uji kelayakan dari ahli menyatakan bahwa model pembelajaran abad 21 berbasis media penanaman karakter bertema nilainilai Pancasila dan sadar konstitusi sangat layak dan kepraktisan model pembelajaran abad 21 berbasis media yang memuat penanaman karakter bertema nilai-nilai Pancasila dan sadar konstitusi adalah sangat praktis. Uji efektifitas model pembelajaran abad 21 berbasis media yang memuat penanaman karakter bertema nilai-nilai Pancasila dan sadar konstitusi menghasilkan putusan efektif dengan hasil perhitungan kemampuan kognitif dan afektif siswa kelas eksperimen lebih baik daripada kelas kontrol, sehingga model pembelajaran abad 21 berbasis media efektif untuk menanamkan karakter siswa dalam mengamalkan nilai Pancasila dan Sadar Konstitusi di sekolah. Prospek penelitian ke depan adalah berupa penelitian tindakan kelas penggunaan model abad 21 berbasis media dalam pembelajaran kelas maya.

\section{Ucapan Terimakasih}

Karya ilmiah ini dipersembahkan untuk kemajuan pendidikan di Indonesia, sehingga ucapan terimakasih kepada Kepala Dinas Pendidikan Pemuda dan Olahraga Kabupaten Wonosobo serta kepada Kepala SD Negeri Wonolelo atas kerjasama dan kolaborasi selama proses pengembangan hingga uji efektifitas melalui eksperimen di sekolah.

\section{Daftar Referensi}

Arikunto, S. 2009. Posedur Penelitian Suatu Pendekatan Praktik. Jakarta: Penerbit Rineka Cipta.

Critcher, CR, Inbar, Y., \& Pizarro, DA. (2012). How Quick Decisions Illuminate Moral Character, 4(3), 308-315. https://doi.org/10.1177/1948550612457688.

Dini, SU. (2009). Instilling Pancasila Value in Children from an Early Age. HUMANIKA, 9, 107-116. 
Fikriyah, A., Safitri, RI, Afriyanti, F., Widya, O., Murti, C., \& Ecology, F. (2014). Komik Pancasila (KOPALA): Pancasila Value Planting Media. IPB Scientific Repository.

Gall, M.D., Gall, J.P and Borg, W.R. (2008). Educational research: An introduction. Pearson Education Inc., Boston.

Gunawan, R. (2013). Pendidkan IPS: Filosofi, Konsep dan Aplikasi. Bandung: Alfabeta.

Kurniawati, E., \& Sunarso, S. (2019). Forming Students' Character through School Culture in Senior High School Taruna Nusantara Magelang. Jurnal Ilmiah Peuradeun, 7(1), 141-162. doi:10.26811/peuradeun.v7i1.298

Lewis, M., \& Ponzio, V. (2016). Character Education as the Primary Purpose of Schooling for The Future. Jurnal Ilmiah Peuradeun, 4(2), 137-146. doi:10.26811/peuradeun.v4i2.92

Lijanporn, S., \& Khlaisang, J. (2016). The Development of Activity-based Learning Using Educational Mobile Application to Enhance Discipline of Elementary School Students The development of activity-based learning models using educational mobile application to enhance discipline of. Procedia - Social and Behavioral Sciences, 174 (February 2015), 1707-1712. https://doi.org/10.1016/j.sbspro.2015.01.825.

Mohd Yusoff, M., \& Hamzah, A. (2015). Direction of Moral Education Teacher to Enrich Character Education. Jurnal Ilmiah Peuradeun, 3(1), 119-132. doi:10.26811/peuradeun.v3i1.58

Purnama, DH, Hubeis, M., \& Matindas, K. (2009). Effectiveness of Learning Communication through Media Website for Physics Teaching Materials (Case of 3rd Grade Students of SMAN 1 Jakarta Pusat). Development Communication Journal, 07(1), 1-12.

Purnama, RP, \& Marsudi. (2017). Development of Science Learning Media for Metamorphosis Material in the Form of Two-Dimensional Animated Video in SDI Little Camel Mojokerto. Journal of Fine Arts, 5(3), 433-454.

Rusman, K.D. \& Riyana, C. (2013). Pembelajaran Berbasis Teknologi Informasi dan Komunikasi. Jakarta: Rajawali Pers. 
Rusmana, IM, \& Isnaningrum, I. (2016). Effectiveness of Use in ICT Media. Formative Journal, 2(3), 198-205.

Sudjana. 2005. Metoda Statistika. Bandung: Tarsito.

Sugiyono. 2009. Metode Penelitian Pendidikan Pendeketan Kuantitatif, Kualitatif, dan RED. Bandung: Alfabeta.

Sukestiyarno, YL. 2013. Olah Data Penelitian Berbantuan SPSS. Semarang: Unnes Press.

Sulistyorini, S. (2014). Development of Science Learning Model Based on Ict (Information and Communication Technology) Or Ict (Information and Communication Technology) in Basic Schools. Journal of Educational Research, 31, 141-146.

Vraga, EK, \& Tully, M. (2015). Effectiveness of a Non-Classroom News Media Literacy Intervention Among Different Undergraduate Populations. Journalism \& Mass Communication Educator, 1-13. https://doi.org/10.1177/1077695815623399.

Wati, EI, Ilyas, M., Sulistyowati, ED, Studi, P., Pendidikan, M., Indonesia, B., \& Mulawarman, U. (2017). Development of Media Mobile Learning, 1(May), 291-304.

Wiwien, K., \& Restu, W. (2019). Effectiveness of Interactive Type Game Media Based on Adobe Flash CS5 Against. Educational Technology Journal, 3(April 2018), 1-10.

Wiyono, S. (2016). Reaktualisasi Pancasila dalam Kehidupan Berbangsa dan Bernegara. Malang: Malang Press. 